\title{
ROBERT ZAWŁOCKI
}

\section{Karnoprawna ochrona środowiska naturalnego}

1. W polskim systemie prawnym obowiązuje wiele przepisów udzielających karnoprawnej (sensu largo) ochrony środowisku naturalnemu. Jednakże w większości przypadków przepisy te określają delikty ściśle związane z regulacjami danej szczególnej ustawy i statuują wykroczenia ${ }^{1}$. W zakresie odpowiedzialności karnej (sensu stricto) ustawodawca jednoznacznie stosuje model jednolitej kodeksowej ochrony środowiska. $Z$ tego względu do najważniejszych przepisów karnych w omawianym zakresie należy zaliczyć przepisy rozdziału XXII Kodeksu karnego, zatytułowanego „Przestępstwa przeciwko środowisku”. W zamiarze prawodawcy przepisy tego rozdziału mają charakter generalny i kompleksowy, tzn. odnoszą się do wszystkich najpoważniejszych rodzajów karygodnych zachowań wobec środowiska naturalnego.

Przywołany rozdział był jednym z niewielu nowych rozdziałów w Części szczególnej Kodeksu karnego z 1997 r. $^{2}$ Stanowił on dobitny przejaw poważnego traktowania przez państwo polskie ochrony środowiska naturalnego. Przyczyną takiej postawy był niewątpliwie rozwój i pogłębienie społecznej świadomości co do szczególnej wagi przyrody w relacjach społecznych i codziennym życiu każdego człowieka.

Kodeksowe unormowanie uczyniło karnoprawną ochronę środowiska zagadnieniem poniekąd nowym, a zarazem atrakcyjnym poznawczo.

${ }^{1}$ Przykładem są tutaj przepisy art. 329-361 ustawy z 27 kwietnia 2001 r. - Prawo ochrony środowiska (t.jedn.: Dz. U. 2013, poz. 1232 ze zm.).

${ }^{2}$ Zob. G. Bogdan, w: A. Zoll (red.), Kodeks karny. Część szczególna. Komentarz do 117-277, Kraków 1999, s. 418-420; W. Radecki, w: A. Wąsek, R. Zawłocki (red.), Kodeks karny. Część szczególna, t. 1, Warszawa 2010, s. 726-728; W. Radecki, Ochrona środowiska w polskim prawie karnym. Cz. I: Pojęcie i zakres prawa karnego środowiska, „Monitor Prawniczy” 1997, nr 12, SIP Legalis. Zob. również: Uzasadnienie rzqdowego projektu nowego kodeksu karnego, „Państwo i Prawo" 1997, z. 3, s. 192. 
Tymczasem problematyka kodeksowych przestępstw przeciwko środowisku naturalnemu jest aktualnie bodajże najrzadziej analizowaną w nauce prawa karnego. Także w praktyce orzeczniczej rzadko stają na wokandzie sprawy o omawiane przestępstwa. Liczba wyroków za ich popełnienie liczona jest w promilach ogółu skazań za przestępstwa.

W konsekwencji orzecznictwo sądów powszechnych i Sądu Najwyższego nie zawiera odpowiedniej bazy dla prowadzenia analiz dogmatycznokarnoprawnych. W ostatecznym efekcie, brakuje odpowiednich naukowych źródeł do przeprowadzenia pogłębionych dogmatycznoprawnych badań nad karną istotą przestępstw przeciwko środowisku. Można również skonstatować, że o ile wzrasta poziom kultury społeczeństwa w zakresie środowiska naturalnego i jego ochrony, o tyle w społeczeństwie brakuje jednak nawyku restrykcyjnego reagowania na przejawy poważnych naruszeń tego dobra.

Celem niniejszego opracowania jest odpowiedź na pytanie o zasadniczą formalnoprawną poprawność wprowadzonych do Kodeksu karnego instrumentów karnoprawnej ochrony środowiska naturalnego. Odpowiedź ta zostanie udzielona $\mathrm{w}$ drodze dogmatycznoprawnej analizy przepisów rozdziału XXII k.k i wskazania wielu bardzo interesujących problemów związanych $\mathrm{z}$ ich ustawową treścią. Już teraz można zgłosić wstępną i ogólną uwagę, że bliższe przyjrzenie się temu rozdziałowi pozwala stwierdzić, że wyróżnia się on na tle wszystkich pozostałych rozdziałów Części szczególnej k.k kilkoma osobliwymi cechami. Sprawiają one, że rozdział XXII k.k. jest niewatpliwie godny uwagi.

2. Dogmatyczno-karnoprawną analizę przepisów ww. rozdziału należałoby rozpocząć od kwestii podstawowej, tj. określenia ich przedmiotu ochrony, czyli dobra prawnego, któremu udzielają one karnoprawnej ochrony. Na płaszczyźnie rodzajowej jest to środowisko naturalne człowieka, obejmujące przyrodę ożywioną i nieożywioną ${ }^{3}$. Naturalne otoczenie człowieka jest niewątpliwie istotną wartością w jego życiu, taką też pozostaje ono w stosunkach ogólnospołecznych. Jest to wartość z natury niewymierna, jednakże bezsporne jest twierdzenie, że zachowanie i rozwijanie środowiska naturalnego służy każdemu człowiekowi i całemu społeczeństwu, a w szczególności pozwala na samorealizację oraz zachowanie biologicznej tożsamości. Uwaga ta jest aktualna również przy uwzględnieniu faktu, że środowisko człowieka staje się coraz bardziej zindustrializowane. Co więcej, można nawet sformułować tezę, że im mniej środowi-

\footnotetext{
${ }^{3}$ Por. W. Radecki, w: A. Wąsek, R. Zawłocki (red.), op. cit., s. 754.
} 
ska naturalnego w życiu człowieka i społeczeństwa, tym bardziej staje się ono dla nich wartościowe (tzn. cenne, aczkolwiek jest to wartość zasadniczo o charakterze niematerialnym).

Szczególną wagę dobra ogólnospołecznego w postaci naturalnego środowiska człowieka wyraża określone usytuowanie omawianych przepisów w strukturze (kolejności Części szczególnej Kodeksu karnego). Kolejność ta nie jest przypadkowa i zależy od rangi danego dobra. W tym kontekście warto odnotować, że przestępstwa przeciwko środowisku znajdują się bezpośrednio przed przestępstwami przeciwko wolności (rozdział XXIII).

Ochrona środowiska naturalnego przed szczególnie szkodliwymi dla niego zachowaniami za pomocą instrumentów prawa karnego jest niewątpliwie uzasadniona ${ }^{4}$. Generalnie ratio legis przepisów rozdziału XXII k.k. sprowadza się do uznania, że naturalne środowisko człowieka jest ogólnospołeczną wartością, którą należy chronić przed poważnymi naruszeniami.

$\mathrm{Na}$ płaszczyźnie indywidualnego przedmiotu ochrony przepisy omawianego rozdziału chronią różne dobra, które w istocie stanowią uprzedmiotowienie środowiska naturalnego. Zatem są to jego części, np. w postaci rzeczy, obiektów, terenów, jak i samego człowieka, a w szczególności jego życia i zdrowia.

3. Przed analizą przepisów omawianego rozdziału należałoby wpierw dokonać jego ogólnego scharakteryzowania. Najlepszym sposobem na przeprowadzenie tego zabiegu jest nazwanie i sklasyfikowanie wszystkich określonych w nim typów czynów zabronionych pod groźbą kary kryminalnej (rodzajów przestępstw przeciwko środowisku). Już w tym miejscu należy odnotować, że zabieg ten jest niezwykle utrudniony ze względu na liczne - nieraz nawet potrójnie - odsyłające dyspozycje tych przepisów.

Przepisy rozdziału XXII k.k. - z uwagi na karnoprawną istotę karalnego zachowania - można podzielić na trzy umowne grupy przestępnych zachowań:

A) niszczenie lub zanieczyszczenie środowiska,

B) obrót materiałami szkodliwymi dla środowiska,

C) wadliwe użytkowanie urządzeń lub nieuprawnione budowanie zagrażające środowisku.

Przeprowadzając ten podział, należałoby zauważyć, że nie wynika on klarownie z treści rozdziału XXII ani z zawartych w nim przepisów. Wprost przeciwnie, trudno w tym przypadku twierdzić o przejrzystym systemie

\footnotetext{
${ }^{4} \mathrm{Na}$ temat koncepcji karnoprawnej ochrony środowiska zob. W. Radecki, Ochrona środowiska w polskim prawie karnym..., passim.
} 
karnoprawnej ochrony środowiska w Kodeksie karnym. Materii ustawowej daleko tutaj od porządku, przejrzystości i spójności. Proponowany podział jest wynikiem racjonalnego uporządkowania omawianych przepisów. Wobec powyższego, już na tym etapie analizy, można uznać, że należałoby ponownie przemyśleć koncepcję kodeksowych przestępstw przeciwko środowisku, chociażby opierając się na ww. wyinterpretowanym podziale.

Do pierwszej grupy (A) przestępstw (niszczenie lub zanieczyszczenie środowiska) należy zaliczyć:

1) umyślne zniszczenie $w$ świecie roślinnym lub zwierzęcym $z$ art. $181 \S 1$,

2) nieumyślne zniszczenie $w$ świecie roślinnym lub zwierzęcym $z$ art. $181 \S 1$ (w art. $181 \S 4$ ),

3) umyślna istotna szkoda na terenie objętym ochroną przyrody z art. $181 \S 2$,

4) nieumyślna istotna szkoda na terenie objętym ochroną przyrody $\mathrm{Z}$ art. $181 \S 2$ (w art. $181 \S 5)$,

5) umyślna istotna szkoda $\mathrm{w}$ gatunku objętym ochroną $\mathrm{z}$ art. $181 \S 3$,

6) nieumyślna istotna szkoda $\mathrm{W}$ gatunku objętym ochroną $\mathrm{z}$ art. $181 \S 3$ (w art. $181 \S 5$ ),

7) umyślne istotne zanieczyszczenie jonizujące $z$ art. $182 \S 1$,

8) nieumyślne istotne zanieczyszczenie jonizujące $\mathrm{z}$ art. $182 \quad \S \quad 1$ (w art. $182 \S 2$ ),

9) umyślne istotne zanieczyszczenie przy eksploatacji instalacji z art. $182 \S 3$,

10) nieumyślne istotne zanieczyszczenie przy eksploatacji instalacji z art. $182 \S 3$ (w art. $182 \S 4$ ),

11) umyślne istotne zanieczyszczenie jonizujące $\mathrm{z}$ następstwami w znacznych rozmiarach $\mathrm{z}$ art. $185 \S 1$,

12) umyślne istotne zanieczyszczenie przy eksploatacji instalacji z następstwami w znacznych rozmiarach $\mathrm{z}$ art. $185 \S 1$,

13) umyślne szkodliwe gospodarowanie odpadami z następstwami w znacznych rozmiarach $\mathrm{z}$ art. $185 \S 1$,

14) umyślne dopuszczenie do popełnienia czynu $z$ art. $183 \S 1$ (art. $183 \S 3$ ) z następstwami $\mathrm{w}$ znacznych rozmiarach $\mathrm{z}$ art. $185 \S 1$,

15) umyślne dopuszczenie do popełnienia czynu $\mathrm{z}$ art. $183 \S 2$ (art. $183 \S 3$ ) z następstwami $\mathrm{w}$ znacznych rozmiarach $\mathrm{z}$ art. $185 \S 1$,

16) umyślne dopuszczenie do popełnienia czynu $\mathrm{z}$ art. $183 \S 4$ (art. $183 \S 3$ ) z następstwami $\mathrm{w}$ znacznych rozmiarach $\mathrm{z}$ art. $185 \S 1$, 
17) umyślny szkodliwy obrót źródłem promieniowania jonizującego $\mathrm{z}$ art. $184 \S 1 \mathrm{z}$ następstwami w znacznych rozmiarach $\mathrm{z}$ art. $185 \S 1$,

18) umyślne dopuszczenie do popełnienia czynu zabronionego $\mathrm{z}$ art. $184 \S 2$ (art. $184 \S 3$ ) z następstwami w znacznych rozmiarach $\mathrm{z}$ art. $185 \S 1$,

19) umyślne istotne zanieczyszczenie jonizujące $\mathrm{z}$ następstwami w postaci ciężkiego uszkodzenia ciała $\mathrm{z}$ art. $185 \S 2$,

20) umyślne istotne zanieczyszczenie przy eksploatacji instalacji z następstwami w postaci ciężkiego uszkodzenia ciała $\mathrm{z}$ art. $185 \S 2$,

21) umyślne istotne zanieczyszczenie jonizujące $\mathrm{z}$ następstwami $\mathrm{w}$ postaci śmierci człowieka $\mathrm{z}$ art. $185 \S 3$,

22) umyślne istotne zanieczyszczenie przy eksploatacji instalacji z następstwami w postaci śmierci człowieka $\mathrm{z}$ art. $185 \S 3$,

23) umyślne istotne niszczenie prawnie chronionego terenu lub obiektu $\mathrm{z}$ art. $187 \S 1$,

24) nieumyślne istotne niszczenie prawnie chronionego terenu lub obiektu z art. $187 \S 2$.

Do drugiej grupy (B) przestępstw (obrót materiałami szkodliwymi dla środowiska) należy zaliczyć:

1) umyślne szkodliwe gospodarowanie odpadami z art. $183 \S 1$,

2) nieumyślne szkodliwe gospodarowanie odpadami $\mathrm{z}$ art. $183 \S 1$ (w art. $183 \S 6$ ),

3) umyślny przywóz z zagranicy substancji szkodliwych z art. $183 \S 2$,

4) nieumyślny przywóz z zagranicy substancji szkodliwych z art. $183 \S 2$ (w art. $183 \S 6$ ),

5) umyślny nielegalny transfer odpadów $\mathrm{z}$ art. $183 \S 4$,

6) nieumyślny nielegalny transfer odpadów $z$ art. $183 \S 4$ (w art. $183 \S 6$ ),

7) umyślne dopuszczenie do popełnienia czynu $\mathrm{z}$ art. $183 \S 1$ (art. 183 $\S 3)$,

8) nieumyślne dopuszczenie do popełnienia czynu z popełnienie czynu zabronionego art. $183 \S 1$ (art. $183 \S 3$ i 6),

9) umyślne dopuszczenie do popełnienia czynu z art. $183 \S 2$ (art. 183 §3),

10) nieumyślne dopuszczenie do popełnienia czynu z art. $183 \S 2$ (art. $183 \S 3$ i 6$)$,

11) umyślne dopuszczenie do popełnienia czynu $\mathrm{z}$ art. $183 \S 4$ (art. $183 \S 3)$,

12) nieumyślne dopuszczenie do popełnienia czynu z art. $183 \S 4$ (art. $183 \S 3$ i 6$)$, 
13) umyślny nieuprawniony transfer odpadów niebezpiecznych $\mathrm{z}$ art. $183 \S 5$,

14) nieumyślny nieuprawniony transfer odpadów niebezpiecznych z art. $183 \S 5$ (w art. $183 \S 3$ i 6 ),

15) umyślny szkodliwy obrót źródłem promieniowania jonizującego $\mathrm{z}$ art. $184 \S 1$,

16) nieumyślny szkodliwy obrót źródłem promieniowania jonizującego z art. $184 \S 1$ (w art. $184 \S 3$ ),

17) umyślne dopuszczenie do popełnienia czynu zabronionego $\mathrm{z}$ art. $184 \S 1$ (w art. $184 \S 2$ ),

18) nieumyślne dopuszczenie do popełnienia czynu zabronionego $\mathrm{z}$ art. $184 \S 1$ (w art. $184 \S 2$ i 3),

19) umyślne szkodliwe gospodarowanie odpadami $z$ następstwami w postaci ciężkiego uszkodzenia ciała z art. 185 § 2,

20) umyślne dopuszczenie do popełnienia czynu z art. $183 \S 1$ (art. 183 § 3) z następstwami w postaci ciężkiego uszkodzenia ciała $\mathrm{z}$ art. 185 § 2,

21) umyślne dopuszczenie do popełnienia czynu $\mathrm{z}$ art. $183 \S 2$ (art. 183 § 3) z następstwami w postaci ciężkiego uszkodzenia ciała $\mathrm{z}$ art. 185 § 2 ,

22) umyślne dopuszczenie do popełnienia czynu $\mathrm{z}$ art. $183 \S 4$ (art. 183 § 3) z następstwami w postaci ciężkiego uszkodzenia ciała $\mathrm{z}$ art. 185 § 2,

23) umyślny szkodliwy obrót źródłem promieniowania jonizującego $\mathrm{z}$ art. $184 \S 1 \mathrm{w}$ postaci ciężkiego uszkodzenia ciała $\mathrm{z}$ art. $185 \S 2$,

24) umyślne dopuszczenie do popełnienia czynu zabronionego $\mathrm{z}$ art. $184 \S 2$ (art. 184 § 3) z następstwami w postaci ciężkiego uszkodzenia ciała $\mathrm{z}$ art. $185 \S 2$,

25) umyślne szkodliwe gospodarowanie odpadami $\mathrm{z}$ następstwami w postaci śmierci człowieka $\mathrm{z}$ art. $185 \S 3$,

26) umyślne dopuszczenie do popełnienia czynu $z$ art. $183 \S 1$ (art. $183 \S 3$ ) z następstwami w postaci śmierci człowieka $\mathrm{z}$ art. $185 \S 3$,

27) umyślne dopuszczenie do popełnienia czynu $z$ art. $183 \S 2$ (art. $183 \S 3) \mathrm{z}$ następstwami w postaci śmierci człowieka $\mathrm{z}$ art. $185 \S 3$,

28) umyślne dopuszczenie do popełnienia czynu $\mathrm{z}$ art. $183 \S 4$ (art. $183 \S 3$ ) z następstwami w postaci śmierci człowieka $\mathrm{z}$ art. $185 \S 3$,

29) umyślny szkodliwy obrót źródłem promieniowania jonizującego $\mathrm{z}$ art. $184 \S 1 \mathrm{w}$ postaci śmierci człowieka $\mathrm{z}$ art. $185 \S 3$,

30) umyślne dopuszczenie do popełnienia czynu zabronionego $\mathrm{z}$ art. $184 \S 2$ (art. $184 \S 3) \mathrm{z}$ następstwami w postaci śmierci człowieka $\mathrm{z}$ art. $185 \S 3$. 
Do trzeciej grupy (C) przestępstw (wadliwe użytkowanie urządzeń lub nieuprawnione budowanie zagrażające środowisku), należy zaliczyć:

1) umyślne niedopełnienie obowiązku utrzymania urządzeń zabezpieczających przez zanieczyszczeniem z art. $186 \S 1$,

2) nieumyślne niedopełnienie obowiązku utrzymania urządzeń zabezpieczających przez zanieczyszczeniem z art. $186 \S 1$ (w art. $186 \S 3$ ),

3) umyślne niedopełnienie obowiązku poprzez dopuszczenie do użytkowania urządzeń zabezpieczających z art. 186 § 2,

4) nieumyślne niedopełnienie obowiązku poprzez dopuszczenie do użytkowania urządzeń zabezpieczających z art. $186 \S 2$ (w art. $186 \S 3$ ),

5) umyślne nieuprawnione budowanie na terenie objętym ochroną $\mathrm{z}$ art. 188 .

Zatem łącznie - w ramach tylko 8 artykułów, zawierających 26 paragrafów, w rozdziale XXII k.k. - można wyróżnić aż 59 (sic!) typów czynów zabronionych przez ustawę pod groźbą kary kryminalnej (rodzajów przestępstw), w tym 17 rodzajów przestępstw nieumyślnych. Już sama liczba przywołanych deliktów musi budzić zdumienie, jest ich bowiem ponad dwa razy więcej niż, np. przestępstw przeciwko mieniu (rozdział XXXV k.k.). Liczba ta sprawia, że rozdział ten uznać należy za jeden z najbardziej obszernych w całej Części szczególnej Kodeksu karnego. Ponadto występuje $\mathrm{w}$ nim najwięcej nieumyślnych typów przestępstw z wszystkich rozdziałów tej części Kodeksu. Przy czym zawarto w nim relatywnie wysoką liczbę przestępstw opartych na konstrukcji narażenia. Dodatkowo występuje w nim najwięcej w Kodeksie karnym typów czynów zabronionych opartych na specyficznej i stosunkowo rzadkiej konstrukcji „dopuszczenia do popelnienia czynu zabronionego”. Co więcej, jest to również rozdział, który obejmuje najwięcej w Kodeksie typów czynów zabronionych opartych na konstrukcji tzw. winy mieszanej (culpa dolo exorta) $)^{5}$.

Wskazanych pięć szczególnych cech rozdziału XX Kodeksu karnego czyni go karnoprawną osobliwością i - paradoksalnie - teoretycznie jednym z najbardziej interesujących rozdziałów Części szczególnej Kodeksu karnego.

4. Przechodząc do omawiania ustawowych znamion typów czynów zabronionych z rozdziału XXII k.k., a w szczególności odnosząc się do znamienia ich podmiotu, należałoby zacząć od bardzo złożonej kwestii

\footnotetext{
${ }^{5}$ Zob. A. Zoll, w: idem (red.), Kodeks karny. Część ogólna, t. 1, Warszawa 2007, s. 125-127.
} 
odpowiedzialności penalnej podmiotów zbiorowych oraz odpowiedzialności karnej reprezentanta podmiotu zbiorowego. Zagadnienie to na gruncie przestępstw przeciwko środowisku jest nader istotne, a to $\mathrm{z}$ uwagi na oczywisty fakt, że w praktyce delikty te są popełniane w ścisłym związku $\mathrm{z}$ funkcjonowaniem zorganizowanych struktur (podmiotów zbiorowych) ${ }^{6}$. To one bowiem są faktycznymi sprawcami szkód wyrządzanych środowisku naturalnemu. Tymczasem odpowiedzialności karnej za przestępstwo może podlegać wyłącznie ściśle określona osoba fizyczna, która odpowiada wyłącznie za swój czyn.

Odpowiedzialność penalną podmiotów zbiorowych określa ustawa z 28 października 2002 r. o odpowiedzialności podmiotów zbiorowych za czyny zabronione pod groźbą kary (t.jedn.: Dz. U. 2012, poz. 768 ze zm.). Zgodnie z art. 16 ust. 1 pkt 8a podmiot zbiorowy podlega odpowiedzialności na podstawie ustawy, jeżeli osoba, o której mowa w art. 3, popełniła przestępstwo przeciwko środowisku, określone w art. 181-184 oraz 186-188 Kodeksu karnego. Na marginesie należy zauważyć, że całkowicie niezrozumiałe jest pominięcie w tym wyliczeniu przestępstwa $\mathrm{z}$ art. $185 \mathrm{k} . \mathrm{k}$.

Przepis art. 3 stanowi zaś, że podmiot zbiorowy podlega odpowiedzialności za czyn zabroniony, którym jest zachowanie osoby fizycznej: 1) działającej $w$ imieniu lub $w$ interesie podmiotu zbiorowego w ramach uprawnienia lub obowiązku do jego reprezentowania, podejmowania w jego imieniu decyzji lub wykonywania kontroli wewnętrznej albo przy przekroczeniu tego uprawnienia lub niedopełnieniu tego obowiązku, 2) dopuszczonej do działania w wyniku przekroczenia uprawnień lub niedopełnienia obowiązków przez osobę, o której mowa w pkt 1,3) działającej w imieniu lub w interesie podmiotu zbiorowego, za zgodą lub wiedzą osoby, o której mowa w pkt 1, 4) będącej przedsiębiorca, który bezpośrednio współdziała $\mathrm{z}$ podmiotem zbiorowym $\mathrm{w}$ realizacji celu prawnie dopuszczalnego - jeżeli zachowanie to przyniosło lub mogło przynieść podmiotowi zbiorowemu korzyść, chociażby niemajątkową. $\mathrm{Z}$ tego i innych przepisów rozważanej ustawy wynika jednoznacznie, że koniecznym warunkiem odpowiedzialności penalnej podmiotu zbiorowego za przestępstwo przeciwko środowisku jest uprzednie pociagnięcie do odpowiedzialności karnej osoby fizycznej będącej jego reprezentantem.

${ }^{6}$ Zob. Uzasadnienie..., s. 193. Sugeruje się tam nie tylko „zbiorowy” charakter podmiotu bezpośrednio odpowiadającego za „zachowanie” godzące w środowisko, lecz także podkreśla, że zachowania takie „pochodzą od wielu podmiotów gospodarczych, których działalność sprzeczna z przepisami o ochronie środowiska sumuje się, powodując znaczne szkody”. 
W szczególności chodzi o osobę fizyczną, która działał w imieniu lub na rzecz takiego podmiotu zbiorowego, np. zakładu zanieczyszczającego środowisko naturalne.

Wskazany wymóg sprawia, że w odniesieniu do omawianej grupy przestępstw konieczne jest zastosowanie tzw. klauzuli odpowiedzialności zastępczej, która pozwala pociagnąć do odpowiedzialności karnej reprezentanta podmiotu zbiorowego niepodlegającego odpowiedzialności karnej wtedy, gdy popełniony czyn zabroniony pod groźbą kary jest wynikiem funkcjonowania tegoż podmiotu? ${ }^{7}$ W pozakodeksowym prawie karnym klauzul takich jest kilkanaście, a w Kodeksie karnym przewidziano ją wyłącznie w art. 308 odnośnie do przestępstw przeciwko wierzycielom (art. 300-302) ${ }^{8}$. Tymczasem rozdział XXII k.k. klauzuli takiej nie przewiduje. Brak ten jest zaskakujący, ponieważ, obok przestępstw gospodarczych, przestępstwa przeciwko środowisku zdają się wręcz modelowym przykładem przestępstw, które wymagają zastosowania ww. klauzuli. Jej brak stawia pod dużym znakiem zapytania możliwość stosowania Kodeksu karnego w tych wszystkich przypadkach, gdy czyny zabronione z rozdziału XXII k.k. zostały popełnione w następstwie działalności podmiotu zbiorowego, czyli w przypadkach bynajmniej nienależących do rzadkości.

W obecnym stanie prawnym można stosować te przepisy wobec reprezentanta tylko wtedy, gdy jego faktyczne zachowanie odpowiada jednej z form zjawiskowych z art. $18 \S 1-3$ k.k., co zdaje się istotnie ograniczać zakres możliwych zastosowań przepisów rozdziału XXII k.k. W związku z tym należałoby w podsumowaniu stwierdzić, że rozdział ten cechuje brak istotnej regulacji, który czyni go w znacznym stopniu dysfunkcjonalnym.

Nie zmienia tej generalnej oceny wprowadzenie przez ustawodawcę do omawianego rozdziału licznych typów czynów zabronionych odwołujących się do konstrukcji: „dopuszczenia (wbrew obowiązkowi) do popełnienia (określonego) czynu zabronionego"". Zapewne konstrukcja ta miała funkcjonować jako swoista klauzula odpowiedzialności karnej zastępczej.

\footnotetext{
${ }^{7}$ Zob. szerzej: R. Zawłocki, Odpowiedzialność karna reprezentanta podmiotu zbiorowego, Warszawa 2013, s. 91 i n.

${ }^{8}$ Ibidem, s. 117 i n.

${ }^{9} \mathrm{Na}$ temat znamienia czasownikowego „dopuszcza” zob. szerzej: R. Dębski, $O$ „,działaniu na szkodę”, ,dopuszczeniu” do zabronionego skutku i zasadzie ustawowej określoności czynu, w: Aktualne problemy prawa karnego. Księga pamiątkowa z okazji Jubileuszu 70. urodzin Profesora Andrzeja J. Szwarca, Poznań 2009, s. 97 i n.
} 
Należałoby jednak krytycznie ocenić taki potencjalny zamysł ustawodawcy. W istocie bowiem regulacja taka nie pełni przywołanej roli, co wynika z trywialnego faktu, że statuuje ona odrębny typ czynu zabronionego i dotyczy odrębnego rodzaju zachowania. Tymczasem, jak już wskazano powyżej, istotą odpowiedzialności karnej zastępczej jest zrealizowanie znamion właściwego typu czynu zabronionego $\mathrm{w}$ ramach specyficznego rodzaju sprawstwa, które dotyczy działania w imieniu lub na rzecz danego podmiotu niepodlegającego odpowiedzialności karnej.

Wracając do problematyki podmiotu rozważanych typów czynów zabronionych (przestępstw przeciwko środowisku), należy wskazać, że zdecydowana większość z nich ma charakter przestępstw powszechnych, które może popełnić każda osoba fizyczna podlegająca odpowiedzialności karnej $^{10}$. Wyjątkiem są tutaj przestępstwa $\mathrm{z}$ art. 186 k.k., które mają charakter indywidualny (właściwy). Ich sprawca działa bowiem „wbrew obowiązkowi”, który ma charakter podmiotowy, a w szczególności określa uprawnienia i obowiązki danej osoby fizycznej, które ją indywidualizują w konkretnej sprawie ${ }^{11}$. Dla koniecznego uzupełnienia należałoby dodać, że za te przestępstwa mogą również odpowiadać osoby współdziałające ze sprawcą indywidualnym, jeżeli spełnione zostaną przesłanki określone w art. $21 \S 2$ k.k.

5. Strona przedmiotowa przestępstw należących do pierwszej grupy związanej z niszczeniem lub zanieczyszczeniem środowiska naturalnego (zob. art. 181, 182, 185, 187 k.k.) została określona w sposób różnorodny.

Znamiona strony przedmiotowej typu czynu zabronionego $\mathrm{z}$ art. 181 k.k. określone są następująco:

1) powoduje zniszczenie w świecie roślinnym lub zwierzęcym w znacznych rozmiarach $(\S 1)$,

2) wbrew przepisom obowiązującym na terenie objętym ochroną, niszczy albo uszkadza rośliny lub zwierzęta, powodując istotną szkodę (§ 2),

${ }^{10}$ Wypada jednak odnotować, że w zakresie przestępstw skutkowych popełnionych przez zaniechanie zastosowanie znajdzie unormowanie zawarte w art. 2 k.k. Oznacza to, że ich sprawcą może być jedynie osoba, na której ciążył szczególny prawny obowiązek zapobieżenia skutkowi (gwarant). W ten sposób krąg potencjalnych sprawców zostaje istotnie zacieśniony, a przestępstwo popełnione przez zaniechanie nabiera indywidualnego charakteru. Zob. M. Królikowski, w: M. Królikowski, R. Zawłocki (red.), Kodeks karny. Część ogólna, t. 1, Warszawa 2011, s. $230 \mathrm{i} \mathrm{n.}$

${ }^{11} \mathrm{Na}$ temat przykładowych źródeł obowiązków, w tym obowiązku ,gwaranta”, zob. P. Nalewajko, w: Kodeks karny. Część szczególna, t. 1, Warszawa 2013, s. 449. 
3) niezależnie od miejsca czynu niszczy albo uszkadza rośliny lub zwierzęta pozostające pod ochroną gatunkowa, powodując istotną szkodę (§ 3).

Przestępstwa określone w tym przepisie mają więc charakter materialny (skutkowy). Czyn zabroniony z $\S 1$ jest znamienny skutkiem w postaci zniszczenia $\mathrm{w}$ świecie roślinnym lub zwierzęcym $\mathrm{w}$ znacznych rozmiarach. Pojęcie ,znacznych rozmiarów” powinno być ujmowane relatywnie, w odniesieniu do cech danego świata roślinnego lub zwierzęcego, $\mathrm{z}$ uwzględnieniem okoliczności danej sprawy ${ }^{12}$. Ustawowo zdefiniowane pojęcie szkody w znacznej wartości w wysokości ponad 200000 zł (zob. art. $115 \S 5$ i 7 k.k.) może stanowić tutaj jedynie pomocnicze kryterium interpretacyjne $^{13}$. Wywołanie tego karalnego skutku może być spowodowane jakąkolwiek czynnością faktyczną, realizowaną przez działanie albo zaniechanie. Omawiany skutek polega wyłącznie na „zniszczeniu”, czyli całkowitym unicestwieniu całego lub części danego świata roślinnego lub zwierzęcego. Jakakolwiek inna jego dysfunkcja, np. odpowiednia do uszkodzenia, nie jest tutaj karalna.

Czyny zabronione z $\S 2$ i 3 są znamienne identycznym karalnym skutkiem w postaci ,istotnej szkody”. W obu przypadkach alternatywnymi czynnościami sprawczymi powodującymi ten skutek są: niszczenie albo uszkadzanie roślin lub zwierzat ${ }^{14}$. W pierwszym przypadku przedmiotem czynności sprawczej są rośliny i zwierzęta występujące na terenie objętym ochroną na podstawie odrębnych przepisów prawa. W drugim zaś: rośliny i zwierzęta pozostające pod ochroną gatunkową (w istocie również na podstawie odrębnych przepisów prawa ${ }^{15}$. Jak wskazano powyżej, trudno jest wyznaczyć ścisły zakres pojęciowy sformułowania ,istotna szkoda”. Generalnie ważne jest zrelatywizowanie tego pojęcia do: danego terenu albo gatunku objętego ochroną oraz do samego przedmiotu, który uległ zniszczeniu lub uszkodzeniu, czyli danych zwierząt lub roślin. Na koniec należy również wskazać, że ważne są tutaj okoliczności danej sprawy. Skutek ten ma więc charakter względny. W konkretnej sprawie może on być spełniony, np. zabiciem chociażby tylko jednego zwierzęcia, a w innej nie będzie spełniony zabiciem wielu. Jest on bowiem swoistą wypad-

${ }^{12}$ Zob. W. Radecki, Znamiona ocenne w rozdziale XII Kodeksu karnego - Przestępstwa przeciwko środowisku, „Ius Novum” 2008, nr 1, s. 16-17.

${ }^{13}$ W. Radecki, w: Kodeks karny..., s. 755. Podobnie: P. Nalewajko, w: Kodeks karny..., s. 453.

${ }^{14}$ Czynnikami wpływającymi na karalność czynu są: 1) miejsce popełnienia czynu zabronionego, 2) obowiązujące na tym terenie „przepisy” oraz 3) skutek czynności sprawczych. Tak: W. Radecki, w: Kodeks karny..., s. 757.

${ }^{15}$ Szerzej na temat ochrony gatunkowej zob. ibidem, s. 760-764. 
kową aspektu ilościowego i jakościowego ujmowaną z uwzględnieniem specyficznych cech danej sprawy (in concreto).

Znamiona strony przedmiotowej typu czynu zabronionego z art. 182 k.k. określone są następująco:

1) czynność sprawcza - zanieczyszczenie wody, powietrza lub powierzchni ziemi substancją albo promieniowaniem jonizującym,

2) przedmiot czynności sprawczej - ilość lub postać zanieczyszczenia wody, powietrza lub powierzchni ziemi stwarzająca wystapienie karalnego skutku,

3) karalny skutek - możliwość: a) zagrożenia dla życia lub zdrowia człowieka lub b) spowodowania istotnego obniżenia jakości wody, powietrza lub powierzchni ziemi lub c) zniszczenia $\mathrm{w}$ świecie roślinnym lub zwierzęcym w znacznych rozmiarach,

4) wyłącznie w zakresie $\S 3$ : okoliczność realizacji czynności sprawczej - związek z eksploatacją instalacji działającej w ramach zakładu, w zakresie korzystania ze środowiska, na które wymagane jest pozwolenie.

Przestępstwo to ma charakter materialny ${ }^{16}$. Przy czym, jak się wydaje, skutek ten polega na specyficznym potencjalnym (abstrakcyjno-konkretnym) narażeniu dobra prawnego na naruszenie ${ }^{17}$. Oznaczałoby to, że omawiany przepis byłby rzadkim w obowiązującym prawie karnym przykładem przestępstwa materialnego z narażenia abstrakcyjnego. Konstrukcja taka stanowi w doktrynie prawa karnego przedmiot istotnych sporów ${ }^{18}$. Bez względu jednak na ich treść, należy zauważyć, że jest ona nader trudna do zastosowania w praktyce. Ustawodawca nie musiał tutaj odwoływać się do tak złożonej konstrukcji. Funkcjonują już w tej mierze sprawdzone niekontrowersyjne konstrukcje, opierające się na następującym schemacie normatywnym: „sprowadza zdarzenie zagrażające..." (zob. art. 163 k.k.), ,sprowadza bezpośrednie niebezpieczeństwo zdarzenia zagrażającego..." (zob. art. 164 k.k. albo art. $296 \S$ 1a k.k.) albo „sprowadza (w określony sposób) niebezpieczeństwo (konkretne)..." (art. 165 k.k.). Tymczasem obowiązująca w art. 182 k.k. formuła opiera się na konstrukcji następującej: „sprowadza (w określony) sposób możliwość zagrożenia (abstrakcyjnego)...”. Należy ją ocenić jednoznacznie negatywnie, chociażby z perspektywy gwarancyjnej funkcji prawa karne-

\footnotetext{
${ }^{16}$ Odmiennie: P. Nalewajko, w: Kodeks karny..., s. 466.

${ }^{17}$ Tak również: W. Radecki, w: Kodeks karny..., s. 773.

${ }^{18}$ Zob. D. Gruszecka, Ochrona dobra prawnego na przedpolu jego naruszenia, Warszawa 2012, s. 75 i n.
} 
go (i to już w jej postaci umyślnej, a tym bardziej w nieumyślnej z § 2). Taka kryminalizacja sprowadzenia możliwości abstrakcyjnego zagrożenia dla dobra prawnego jest konstrukcją sięgająca bodajże dalej niż konstrukcja przygotowania przestępstwa, które co do zasady karalne nie jest. Uznać ją więc należy za wysoce wadliwą, a w szczególności uragającą podstawowym zasadom prawidłowej kryminalizacji. Konkluzja ta pozwala pominąc dalszą dogmatyczną analizę tego przepisu, ponieważ sprowadza się do postulatu jego całkowitego przemodelowania.

Znamiona strony przedmiotowej typu czynu zabronionego z art. 185 k.k. określone są następująco:

1) popełnienie czynu zabronionego $\mathrm{z}$ art. $182 \S 1$ lub 3 , art. $183 \S 1$ lub 3 lub w art. $184 \S 1$ lub 2,

2) wywołanie przez sprawcę ww. czynu następstwa w postaci:

a) zniszczenia $\mathrm{w}$ świecie roślinnym lub zwierzęcym $\mathrm{w}$ znacznych rozmiarach lub istotnego obniżenia jakości wody, powietrza lub powierzchni ziemi ( $(1)$,

b) ciężkiego uszczerbku na zdrowiu człowieka,

c) śmierci człowieka lub ciężkiego uszczerbku na zdrowiu wielu osób.

Karnoprawna istota tego typu czynu zabronionego, o wybitnie odsyłającym charakterze, sprowadza się właściwie do kryminalizacji skutku, który stanowi ziszczenie się zagrożenia kryminalizowanego w przepisach bazowych $^{19}$. Jest to rozwiązanie podobne do przyjętych w art. $163 \S 3$ i $165 \S 3$ k.k. Należy jednak zwrócić uwagę, że w tych przepisach karalne następstwo jest ziszczeniem się zagrożenia co najmniej konkretnego. Tymczasem w art. 185 k.k. kryminalizuje się ziszczenie możliwości zagrożenia abstrakcyjnego. W konsekwencji powstają tutaj istotne problemy natury kauzalnej. Brakuje bowiem wyrażonego w ustawie elementu, który pozwalałby połączyć karalne następstwo z art. 185 k.k. z karalnymi skutkami z art. 182, 183 i 184 k.k. Jeżeli bowiem ich sprawca wywołuje tylko możliwość abstrakcyjnego zagrożenia, to pełne urzeczywistnienie się tego zagrożenia nie może być opierane wyłącznej na jego „bazowym” czynie.

Prowadzi to do generalnego wniosku, że konstrukcja i treść typu czynu zabronionego z art. 185, odsyłającego do wadliwych art. 182, 183 i 184 k.k., jest tym bardziej wadliwa. Wobec czego również w tym przypadku w perspektywie formułowanie postulatów de lege ferenda - można zaniechać dalszej analizy dogmatycznej.

${ }^{19}$ Zob. P. Nalewajko, w: Kodeks karny..., s. 491. 
Znamiona strony przedmiotowej typu czynu zabronionego z art. 187 k.k. określone są następująco:

1) czynności sprawcze - niszczy, poważnie uszkadza lub istotnie zmniejsza wartość przyrodnicza prawnie chronionego terenu lub obiektu,

2) skutek czynności sprawczej - spowodowanie (powoduje) istotna szkode.

Odnosząc się do przywołanego ustawowej typizacji karalnego zachowania, należy w pierwszej kolejności odnotować, że ustawodawca prezentuje tutaj kolejną koncepcję karnoprawnej ochrony przyrody przed jej zniszczeniem. W art. 181 odwoływał się do konstrukcji ,powodowania zniszczenia w znacznych rozmiarach”, w art. 182 - ,zanieczyszczenia mogącego spowodować zniszczenie w znacznych rozmiarach", w art. 185 - ,wywołania następstwa zniszczenia w znacznych rozmiarach”. Tymczasem w analizowanym art. 187 wskazuje się na „niszczenie powodujące istotną szkodę". Jest to więc już czwarty odrębny sposób kryminalizacji zniszczenia, przy czym żaden z nich nie nawiązuje do konstrukcji tradycyjnie stosowanych w polskich kodeksach karnych, by przywołać chociażby klasyczne przestępstw zniszczenia (mienia) z art. 288 k.k.

Po drugie, nawiązując już do konstrukcji ww. przestępstwa zniszczenia mienia, ustawodawca bez wyraźnych powodów nie przeprowadził w art. 187 k.k. kryminalizacji - przewidzianego w art. 288 k.k. - ,uczynienia (terenu/obiektu) niezdatnego do użytku". Po trzecie, poddał on kryminalizacji ,istotne zmniejszenie wartości (terenu obiektu)”, co rodzi pytanie o znaczenie tego sformułowania w kontekście innego przewidzianego znamienia, tj. ,poważnego uszkodzenia”. Po czwarte, trudno zracjonalizować decyzję o kryminalizacji jedynie ,poważnego uszkodzenia”20 i „istotnego zmniejszenia wartości”, a nie po prostu „uszkodzenia” i „zmniejszenia wartości”. Tym bardziej że czynności te stanowią z woli ustawodawcy przesłankę karalnego skutku w postaci „poważnej szkody”21. Można wtedy sformułować tezę, że negatywna waga czynności sprawczych nie ma znaczenia wobec wymogu wywołania tymi czynnościami wysoce negatywnego skutku. W skrajnych przypadkach (in concreto) można sobie wyobrazić sytuację, że z jednej strony poważne uszkodzenie (obiektu) mimo wszystko nie wywołuje istotnej szkody,

${ }^{20} \mathrm{Na}$ ten temat zob. ibidem, s. 504.

${ }^{21}$ Por. W. Radecki, w: Kodeks karny..., s. 816. Autor zwraca uwagę, że mamy tu do czynienia z podwójną ,istotnością”. Pomijając trudności związane z ustaleniem treści wskazanych znamion ocennych, należy zwrócić uwagę na specyficzne (i istotnie problematyczne) również „podwójne” ujęcie znamienia skutku. 
a uszkodzenie „mniej-niż-poważne” - szkodę taką jednak wywoła. Po piąte, ustawodawca nie dookreślił charakteru szkody, wskazując jedynie na jej wagę (istotność). W rezultacie nie wiadomo, o jaką (w czym) szkodę chodzi. Można domniemywać, że intencją ustawodawcy jest szkoda w prawnie chronionym terenie lub obiekcie o charakterze przyrodniczym. Jednakże domniemanie to $\mathrm{z}$ pewnością nadużywa wymogów precyzyjnego określania ustawowych znamion typu czynu zabronionego pod groźbą kary kryminalnej.

Wszystkie przywołane powyżej wady regulacji z art. 187 k.k. pozwalają również w tym przypadku konkludować, że przepis ten powinien być co najmniej istotnie skorygowany.

6. Jak już wskazano powyżej, na drugą grupę przestępstw przeciwko środowisku składają się przepisy art. 183 i 184 k.k., określające generalnie przestępstwa polegające na obrocie materiałami szkodliwymi dla środowiska naturalnego. Karnoprawną istotą przestępstwa z art. 183 k.k. jest niedozwolony obrót odpadami lub substancjami zagrażającymi środowisku, a z art. 184 k.k. - niedozwolony obrót źródłem promieniowania jonizującego. Podstawową różnicą jest tutaj odmiennie określony przedmiot czynności sprawczych, który zresztą nie ma charakteru kategorialnego. Można bowiem z powodzeniem przyjąć, że źródło promieniowania jonizującego stanowi substancję zagrażającą środowisku ${ }^{22}$. Przywołana okoliczność uprawnia do zbiorczej analizy tych przestępstw. Prowadzi ona do następujących wniosków. Po pierwsze, przepisy te są nadmiernie kazuistyczne. Po drugie, nie mają charakteru ,symetrycznego". Określone typy karalnych zachowań statuujące szczególne typy czynów zabronionych w art. 183 k.k. stanowią jeden $\mathrm{z}$ elementów typu podstawowego z art. 184 k.k. Wydaje się przy tym, że to drugie rozwiązanie jest właściwe. Wskazana ,asymetryczność" tych regulacji związana jest również z faktem, że przy identycznej istocie typu zachowania karalnego, ustawodawca odmiennie formułuje czynności sprawcze. W rezultacie w art. 183 k.k. przewidziano czynności nieprzewidziane w art. 184 k.k., i odwrotnie. W tym zakresie niewątpliwie brakuje ustawowej spójności. Po trzecie, przewidziane w tych dwóch przepisach czynności sprawcze - ujmowane nawet zbiorczo - nie wyczerpują kompletu czynności sprawczych związanych z karalnym niedozwolonym obrotem. Jest to wynik nieudolnej ze strony ustawodawcy

\footnotetext{
${ }^{22} \mathrm{Na}$ temat pojęcia substancji zagrażającej środowisku zob. P. Nalewajko, w: Kodeks karny..., s. 475-476.
} 
próby odrębnego stypizowania takiego zachowania na użytek rozdziału XXII k.k., bez odwołania się do tradycyjnych rozwiązań karnoprawnych w tym względzie. Swoistym wzorcem są tutaj przepisy art. 53-56 ustawy z 29 lipca 2005 r. o przeciwdziałaniu narkomanii (Dz. U. 2005, Nr 179, poz. $1485 \mathrm{ze} \mathrm{zm}$.). Przepisy te przewidują następujące karalne sposoby obrotu (środkami odurzającymi lub substancjami psychotropowymi): „wytwarza, przetwarza, przerabia, posiada, przechowuje, zbywa, nabywa; dokonuje: przywozu, wywozu, przewozu, nabycia, dostawy; wprowadza do obrotu albo uczestniczy w takim obrocie". Można również przywołać rozwiązanie z art. 171 k.k. (przestępstwo obrotu niebezpiecznymi środkami), w którym m.in. przewidziano czynności określone jako: „posługuje się, handluje oraz odstępuje innej osobie". Wskazane przepisy pozwalają sformułować optymalną konstrukcję przestępstwa niedozwolonego obrotu. Odnosząc do niej omawiane przepisy art. 183 i 184 k.k., należy zauważyć, że co do zasady konstrukcja ta nie jest realizowana. Okoliczność ta czyni te przepisy regulacjami w znacznej mierze dysfunkcjonalnymi i jednocześnie stanowi podstawę ich koniecznej zmiany. Wydaje się, że jej istota powinna sprowadzać się do zaproponowania jednego jednolitego przepisu przewidującego wymagany komplet ww. czynności sprawczych.

7. Trzecia grupa przestępstw przeciwko środowisku związana jest z wadliwym użytkowaniem urządzeń (art. 186 k.k.) oraz z nieuprawnionym budowaniem zagrażającym środowisku (art. 188 k.k.).

Strona przedmiotowa typu czynu zabronionego z art. $186 \S 1$ k.k. została określona następująco:

1) czynności sprawcze: a) nieutrzymanie w należytym stanie lub b) nieużywanie,

2) przedmiot czynności sprawczych: a) urządzenie zabezpieczające wodę, powietrze lub powierzchnię ziemi przed zanieczyszczeniem lub b) urządzenie zabezpieczające przed skażeniem promieniotwórczym lub promieniowaniem jonizującym $^{23}$,

3) okoliczność czynności sprawczych: naruszenie określonego obowiązku.

Karnoprawna istota omawianego zachowania (przestępstwa formalnego $^{24}$ ) sprowadza się do karalnego zaniechania właściwego używania odpowiednich urządzeń oraz karalnego używania tych urządzeń w niewła-

\footnotetext{
${ }^{23}$ Zob. W. Radecki, w: Kodeks karny..., s. 805-806.

${ }^{24}$ P. Nalewajko, w: Kodeks karny..., s. 499.
} 
ściwy sposób. Wobec tego należy stwierdzić, że ustawodawca poddał kryminalizacji tylko nieznaczny fragment przywołanego karygodnego zachowania. Zaniechanie właściwego używania urządzeń nie sprowadza się wyłącznie do całkowitego zaniechania jego używania, ale również np. do braku używania jego części (albo jednego z zespołu obiektów) ${ }^{25}$. Ponadto niewłaściwe używanie urządzeń to nie tylko nieutrzymywanie ich w należytym stanie, lecz także np. używanie ich niezgodnie z przeznaczeniem lub warunkami użytkowania.

Dodać należy, że w przepisie tym ustawodawca całkowicie określa przedmiot czynności sprawczych w liczbie mnogiej, co niewattpliwie nie jest właściwym rozwiązaniem. Ponadto, wbrew logice ustawodawczej tego rozdziału, pomija się w art. $186 \S 1$ k.k. kryminalizację dopuszczenia do popełnienia tego czynu zabronionego. Przepis ten wymaga więc istotnego uzupełnienia i korekty.

Całkowicie odrębny typ czynu zabronionego określono w $\S 2$ art. 186 k.k. Jego stronę przedmiotową określono w sposób następujący: „oddaje lub wbrew obowiązkowi dopuszcza do użytkowania obiekt budowlany lub zespół obiektów niemających wymaganych prawem urządzeń zabezpieczających wodę, powietrze lub powierzchnię ziemi przed zanieczyszczeniem lub urządzeń zabezpieczających przed skażeniem promieniotwórczym lub promieniowaniem jonizującym".

Zwraca tutaj uwagę kategorialna niespójność pomiędzy tą regulacją a przestępstwem z $\S 1$. Przepis $\S 2$ dotyczy zachowania, które umożliwia funkcjonowanie obiektu, w którym brakuje odpowiednich urządzeń. Tymczasem w $\S 1$ chodzi wyłącznie o użytkowanie tych urządzeń. Wynika z tego, że w ogóle nie poddano kryminalizacji niewłaściwego użytkowania obiektów, w których znajdują się te urządzenia. Ta istotna luka legislacyjna niewątpliwie nie była zamierzona $\mathrm{i}$ wymaga odpowiedniego uzupełnienia.

Dodać należy, że $§ 2$ również zawiera lukę, ponieważ obejmuje tylko „oddanie”, z pominięciem „dopuszczenia do oddania” (obiektu budowlanego). W rezultacie, $\mathrm{z}$ całkowicie niezrozumiałych przyczyn, w przepisie tym kryminalizuje się dopuszczenie do użytkowania i pomija niewłaściwe użytkowanie oraz kryminalizuje oddanie do użytkowania i pomija dopuszczenie do oddania.

${ }^{25}$ W literaturze wskazuje się jednak, że de lege lata pojęcie „nieużywania” obejmuje obok całkowitego niekorzystania również niekorzystanie z istotnej funkcji urządzeń zabezpieczających. Zob. ibidem, s. 497. Zob. również: J. Sobczak, w: R. A. Stefański (red.), Kodeks karny. Komentarz, Warszawa 2014, Nb 4, SIP Legalis. 
Strona przedmiotowa typu czynu zabronionego z art. 188 k.k. składa się z trzech elementów:

1) okoliczności (miejsca) realizacji czynności sprawczych (teren objęty ochroną ze względów przyrodniczych albo jego otulina oraz teren objęty ochroną ze względów krajobrazowych albo jego otulina),

2) naruszenia obowiązujących przepisów (zachowanie sprawcy - sprowadzające się wyłącznie do dwóch pierwszych czynności sprawczych „wbrew przepisom”, określającym uprawnienia i obowiązki budowania na terenach objętych ochroną przyrody lub krajobrazu),

3) trzech alternatywnych czynności sprawczych: wznoszenie nowego obiektu budowlanego, powiększenie istniejącego obiektu budowlanego albo prowadzenie działalności gospodarczej zagrażającej środowisku ${ }^{26}$.

Wskazany sposób kryminalizacji (przestępstwa formalnego) jest niezupełny co najmniej z dwóch powodów. Po pierwsze, przywołane czynności sprawcze są karalne tylko, gdy są realizowane wbrew przepisom ${ }^{27}$, a nie także wtedy, gdy naruszają decyzję wydaną na podstawie określonych przepisów (co w praktyce wydaje się ewentualnością występująca częściej). Po drugie, czynności te nie obejmują rozbudowy budynku, która nie polega na jego powiększeniu, lecz np. na pomniejszeniu. Kazuistyczne określenie czynności sprawczych czyni więc ten przepis w znacznej mierze dysfunkcjonalnym. Dwie pierwsze czynności sprawcze można popełnić tylko przez działanie, trzecia zaś może być popełniona przez działanie albo zaniechanie. Wskazane działanie i zaniechanie muszą mieć charakter trwały, ponieważ odnoszą się do czynności sprawczej, na którą składa się wiele faktycznych zachowań się sprawcy. Charakter tej ostatniej, ujmowany w relacji do dwóch poprzednich, właściwie konstytuuje odrębną odmianę omawianego przestępstwa. W każdej jego odmianie wykazuje ono charakter formalny. Przy czym prowadzenie działalności gospodarczej zagrażającej środowisku dotyczy zagrożenia abstrakcyjnego dla środowiska naturalnego. Kryminalizacja tego rodzaju zagrożenia, w kontekście ogólnie ujętej czynności sprawczej oraz dobra prawnego sprawia, że granice i treść zachowań karalnych są tutaj wyznaczone w sposób niejasny, co pozwala również wobec tej odmiany przestępstwa sformułować zarzut dysfunkcjonalności.

8. Niemal wszystkie przestępstwa określone w tym rozdziale mają charakter umyślny oraz nieumyślny. Niewątpliwie ustawodawca nie prze-

\footnotetext{
${ }^{26}$ Por. W. Radecki, w: Kodeks karny..., s. 822.

${ }^{27} \mathrm{Na}$ temat wskazanego znamienia zob. ibidem, s. 823-825.
} 
strzegał przy typizacji zachowań godzących w środowisko naturalne zasady ultima ratio kryminalizacji zachowań nieumyślnych w wyjątkowych przypadkach. Naruszenie tej zasady wydaje się tutaj tyleż oczywiste, co nieuzasadnione. Tym bardziej że - jak wynika z przeprowadzonej powyżej analizy płaszczyzn przedmiotowych tych przestępstw - zakres karalności często został w nich określony niejednoznacznie. Niewyraźne granice strony przedmiotowej konsekwentnie potęgują nieoznaczoność granic karalności na płaszczyźnie strony podmiotowej. W rezultacie karalna nieostrożność przy omawianych przestępstwach odnosi się do zachowań, które trudno określić mianem psychicznie nagannych (karygodnych).

9. Wszystkie omawiane przestępstwa są występkami publicznoskargowymi i są ścigane ,z urzędu”. Zgodnie z art. 304 k.p.k. każdy, dowiedziawszy się o popełnieniu przestępstwa ściganego z urzędu, ma społeczny obowiązek zawiadomić o tym prokuratora lub policję (§ 1$)$, a instytucje państwowe i samorządowe, które w związku ze swą działalnością dowiedziały się o popełnieniu przestępstwa ściganego z urzędu, są obowiązane niezwłocznie zawiadomić o tym prokuratora lub policję oraz przedsięwziąć niezbędne czynności do czasu przybycia organu powołanego do ścigania przestępstw lub do czasu wydania przez ten organ stosownego zarządzenia, aby nie dopuścić do zatarcia śladów i dowodów przestępstwa (§ 2).

10. Przeprowadzona powyżej analiza prowadzi do generalnej bardzo krytycznej oceny rozwiązań zawartych w rozdziale XXII k.k., a w związ$\mathrm{ku} \mathrm{z}$ tym - konkluzji o pilnej potrzebie przeprowadzenia wielu istotnych zmian w tym rozdziale. Przywołane powyżej, jego liczne osobliwości okazują się bowiem jego istotnymi wadami. W szczególności nie można wskazać chociażby jednego przepisu, który nie zawierałby istotnego błędu. Potrzebna jest więc tutaj korekta systemowa, sprowadzająca się do całkowitego przeformułowania, a nawet określenia na nowo deliktów zawartych w rozdziale XXII k.k. Dobrą okazją do realizacji tego zabiegu są prowadzone obecnie przez Komisję Kodyfikacyjną Prawa Karnego przy Ministrze Sprawiedliwości pracę nad propozycjami zmian w Części szczególnej Kodeksu karnego.

Wydaje się, że przedstawione błędy legislacyjne są głównym powodem ograniczonego stosowania ww. przepisów w praktyce ścigania i wymiaru sprawiedliwości. Oznaczałoby to, że kodeksowa karnoprawna ochrona środowiska naturalnego ma obecnie charakter symboliczny i fik- 
cyjny właśnie $\mathrm{z}$ tego powodu. Postulowana reforma rozdziału XXII k.k. miałaby zatem na celu wprowadzenie rzeczywistej karnoprawnej ochrony środowiska naturalnego w Polsce.

\title{
PROTECTION OF NATURAL ENVIRONMENT IN CRIMINAL LAW
}

\author{
Sum mary
}

The aim of this paper is to answer the question of the formal and legal adequacy of instruments introduced to the Criminal Code to protect the natural environment. The regulation of its Chapter XXII has been analysed.

The author formulates a critical assessment of the regulation and postulates gross amendments to it. The necessary systemic correction should not only consist in substantial reformulation, but also a redefinition of the delicts referred to in the analysed chapter. It seems that the redrafting works currently being conducted by the Criminal Law Codification Committee at the Minister of Justice are a good occasion to implement the necessary amendments. What is needed is the elimination of the legislative errors which are the main obstacle today, and which reduce the scope of, or the extent to which the currently available provisions are applied in practice. As a result, the symbolic and fictitious character of the protection of natural environment in criminal law would make that protection a feasible reality.

\section{LA TUTELA PENALE DELL'AMBIENTE}

\author{
Riassunto
}

Lo scopo dello studio è di rispondere alla domanda sulla sostanziale correttezza di natura formale e giuridica degli strumenti di tutela penale dell'ambiente introdotti nel Codice penale. Da questo punto di vista all'analisi è stato sottoposto il Capitolo XII del codice penale.

In conclusione l'autore valuta la regolamentazione inclusa nel capitolo in oggetto in maniera critica e formula il postulato di procedere alla sua sostanziale modifica. Servono le modifiche sistemiche, volte alla totale riformulazione, persino alla determinazione ex novo delle trasgressioni incluse nel Capitolo XXII del codice penale. Un'ottima occasione al fine di realizzare questo compito sono i lavori volti a proporre modifiche nella Parte specifica del Codice civile svolti dalla Commissione di Codificazione del Diritto Penale presso Il Ministero della Giustizia. Sembra che gli errori legislativi indicati nell'articolo siano la causa principale dell'applicazione limitata delle regole analizzate nella prassi investigativa e nella giustizia. Ciò significherebbe che la tutela penale dell'ambiente sia di carattere simbolico e fittizio proprio per questo motivo. Per cui la riforma postulata avrebbe lo scopo di introdurre la reale tutela dell'ambiente. 